\title{
Reinforced concrete prototypes for the factory in Italy (1950-1975) The architectural expressive machines
}

\author{
Quadrato, Vito \\ Ph.D student, University of RomaTRE / Politecnico di Bari. vito.quadrato@poliba.it
}

https://doi.org/10.4995/CIAB8.2018.7608

\begin{abstract}
The relationship between architectural expressiveness and concrete formal structure was the leitmotif of the Italian structuralism in the second post-war two decades.
\end{abstract}

The design of industrial structures radicalized this relationship because of the nature of the production processes that imposed to the architect the dimension of standardisation, repetition and economy of means. This approach reduced the distance between architectural form and informal building.

This research aims to show how this condition transforms the idea of design process by some Italian authors, in the restricted field of reinforced-concrete structures for industry. The architectural form becomes a process that includes all the aspects of the project: the technological content (cooling, ventilation and water-drainage systems), the economic side, the engineering start up. In this way, the project of industrial structures is an outcome of the components design, constituted by structural elements (pillars, beams, desk boards), and controlled by the project of a structural bay, as a device for the design process.
In this sense, the proposed paper shows the research on the Kodak factory in Marcianise by Aldo Favini and Gianluigi Ghò as a paradigm of this phenomenon. The paper illustrates how the hollow structural form of the elements addresses the problem of the technological content in the architectural design, showing morphological-structural models that isolates the bay as a design device. This aspect defines a specific quality of the industrial prototypes, developed through the professional partnership between the architect and the engineer. The knowledge about this kind of industrial prototypes is useful on one hand to admit these building as an Italian historical heritage that needs to be preserved, on the other hand to understand how it is possible transform these buildings through a new adaptive reuse.

Key words: Industrial heritage; Structural form; Culture of technology; Memory of places. 

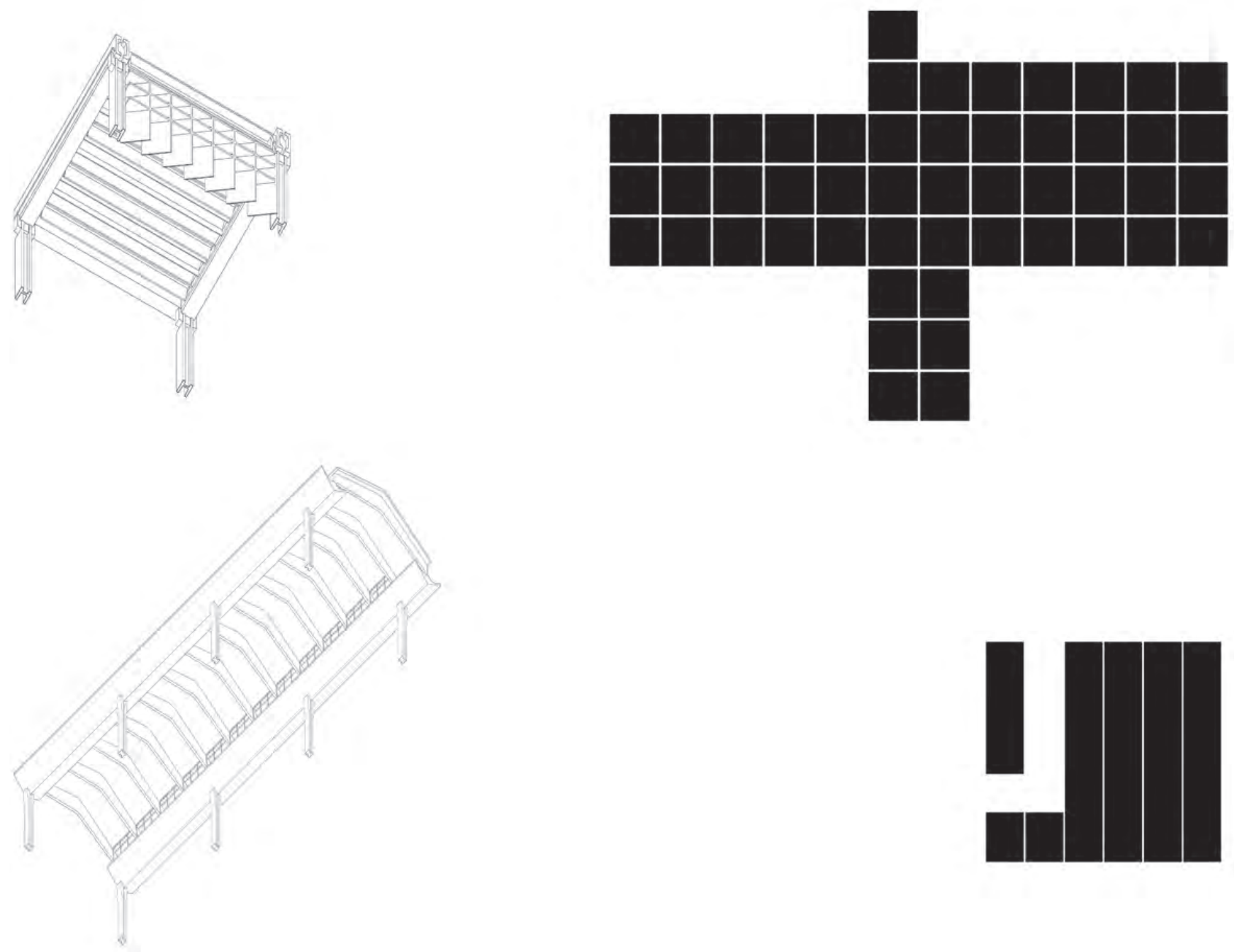

Figure 1. Structural pattern comparison with Kodak factory in Marcianise (G. Ghò, A. Favini) and Cedis Factory in Palermo (A. Zanuso). Vito Quadrato. 2017. Developed on the base of drawings coming from Fondo Zanuso (Archivio del Moderno Accademia di Mendrisio), Fondo Favini (Politecnico di Milano).

Reinforced concrete prototypes for the factory in Italy (19501975). The architectural expressive machines

\section{An introduction to the Aesthetic of Modernist concrete form in Italy}

On the aesthetic of the concrete, the second pre-war season proposed the extraordinary experience of Italian Rationalism. The Gruppo 7 viewed the possibility of this construction technique to recover "the harmonies, the symmetries in the new construction schemes, within the materials characters there is the perfect cor- respondence to the designated requirements of building"1. This idea of a new classic, some time away from the Fascist rhetoric, has been confirmed by the emblematic Manifesto of Esposizione italiana di architettura razionale, in 1928: the axonometric view of a reinforced concrete pillar, which left uncovered, on the top the steel reinforcement. The iconographical message lends itself to a double interpretation: on one hand suggests the idea of a potential, unfinished element, which can lead to a new Modern architecture, on the other hand the visual caesura between the top and the frame of the pillar, seems to ask for a new classic and figurative culmination ${ }^{2}$. 
The period between 1950 and 1975 seems, in some way, to tie on with this image. Indeed the debate on the relationship between form and structure in the architectural organism reawakened, enhancing the theoretical interest with a practical and experimental interest, in which the reinforced concrete construction recovered a specific field of research.

The critical reading of the structural and architectural innovations in the field of reinforced concrete, requests to focus on a specific aspect of the phenomenon.

The paper proposes to research on the issue of the utilitarian structures, in particular the concrete factories built between 1950 and 1975. Indeed, the topic of the useful form further radicalized the relationship between architectural expressiveness and structure because of the production processes that were imposed upon the architect; that of, the dimension of standardisation, repetition and economy of means. This approach reduced the distance between architectural form and informal building. Felix Candela stresses that " the history of architecture provides only a partial overview of the past, by the exclusive reference to monumental buildings [...] in which the structure plays a dominant role, instead, it does not focus much on the research and description of strictly utilitarian works. However, these modest and nearly anonymous buildings represent the habitual work of the architects. Within these works, it is reasonable employ only structural types firmly established in the habitual practice, whose restrictions and possibilities are part of a basic understanding by ordinary professionals" ${ }^{\prime 3}$. This extract is a part of a critique which Candela refers to Pierluigi Nervi's work, to whom the Spanish architect accused of proposing, through his idea of structural architecture, an elite experimentation on the reinforced concrete relegated to a dimension non-exportable to an ordinary design process and, for this reason, condemned to a condition of monumental exceptionality.

Furthermore, it doesn't seem wrong to affirm that, on the issue of concrete form experimentation in Italy, most of the research focus on Pierluigi Nervi, Riccardo Morandi and Sergio Musmeci's experience, which operated in the field where the idea of "structural invention" and "static intuition" ${ }^{4}$ were employed in order to obtain a complex architectural shape.

However, beyond these exceptional cases, in which the designer can centralize within a personal operational dimension the question of the relationship between Concrete form and the technical aspects of the project, in those same years there was a more ordinary condition on the design of factories. According to that approach of the architect and engineer, even if their positions are distinguishable, converged on an idea of architectural expressiveness of the industrial structure, in respect of a complex programme requested by the customer. The architect accepts the engineer's operational cri- teria pre-suppositions regarding to "the confidence in the analytical method, decomposing the structural units in a convenient series of basic elements that can be expressed and studied mathematically" and that "there is no a priori form, it is originated by the conceptual articulation of a technical problem" . Nevertheless, the architect tries to identify a "restricted area" of architectural and formal expressiveness.

The architectural expressive machines. The hollow concrete structural form of the Kodak factory in Marcianise

The particular category of reinforced concrete prototypes, built in Italy between 1950 and 1975, proof of this different design approach. These prototypes regarded a specific type of factory, the single-storey reiterated bay. In those years, the development of prototypes is affected by the adoption of prefabricated structural elements; this phenomenon introduces the problem of spatial modulation in which "the prefabricated system puts into action the bold industrial chain of production and assembly and becomes an architectural work as a prototype of forms expressive figuration"6. This operative pre-supposition influences the design process, forcing the designer to identify precisely the structural elements (beams, pillars, deck boards), linked to the tectonic assembly system that guarantees the expressiveness of the concrete shape. This structural system corresponds to the "modulo-oggetto" ical and structural device that is repeatable, extensible and flexible respect to the industry needs.

This approach is definable as "classic", addressing to the codification of a structural language based on a typological range, in which each element is recognizable as component of the architectural organism. Indeed, Vittorio Ugo noted an implicit allusion to the idea of classic within the identification between design process and assembly process: " a doric temple or a gothic cathedral, with a distinction between the Modern concept of industrialisation and the industries of certain times in history, are based on a number of material components and dimensional relationships, whose typological range is quite limited."

The Italian experience shows how the tendency to standardize and catalogue structural elements does not correspond to the disappearance of an authorial design, on the contrary, it is possible to preserve a traditional approach on the design of reinforced concrete component, through a direct encounter with architect, engineer and producers.

It is possible to distinguish two-construction category for the single-storey factories: the first one regards structures based on linear elements; the second one regards structures based on form working elements. In the first case the design of structural pattern focuses on the cross section analysis of the elements, forming the 

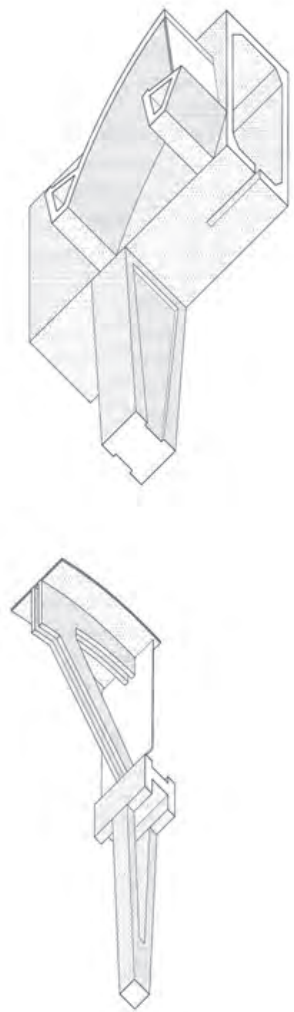
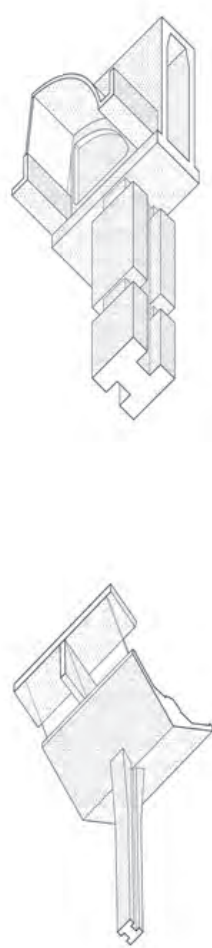
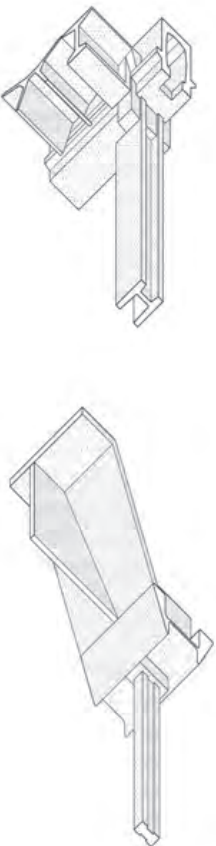
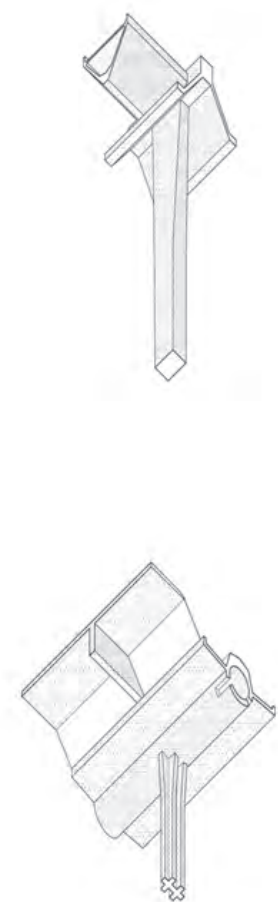

Figure 2. Axonometric bay system of reinforced concrete industrial prototypes. (From the left to the right: A. Favini, C. R. Clerici, Perugina Factory, Perugia 1961; M. Zanuso, Necchi Factory, Pavia 1961; A. Favini, G. Ghò, Kodak Factory, Marcianise1972-75; E. Vittoria, M. Zanuso, A. Migliasso, Olivetti Factory, Scarmagno, 1962-72; R. Nello, Olivetti woodworking, San Bernardo d'Ivrea 1952-53; M. Zanuso, Cedis Factory, Palermo, 1955; A. Migliasso, Asti factory, Asti, 1965; M. Zanuso, Olivetti Factory, Merlo 1954-61 ) Vito Quadrato (2017).

framework. Such structures are governed by the principle of tectonic assembly in which each element has a dual nature: it has an autonomous shape that reflects the role of the elements in the discharge of forces; both, at the same time have a discontinuity that refers to the connection with the others structural elements. In the second case, each element is a frame of a structural continuum, undistinguishable as part of a whole. From a strictly structural point of view, the difference between these two categories is clear: the structures based on linear elements correspond to bending forces, so they are "inactive structures"10; the structure based on form working elements deviate the bending forces, taking advantage from the formwork resistence, so they are "active structures".

Indeed, even if in both cases these categories refer to the archetype of Hypostyle Hall, the structures based on linear elements attached to the traditional construction of the thrilitic system, and then to the architrave portal within each element is intelligible. Instead, the structures based on form working elements refer to an organic and naturalistic hypostyle whose meaning is understandable in the interior space of the building, within the void created by the mass of the structure.

These constructive categories admit different kind of structural hierarchies, in which both the form and the topological value of the structural elements influences the sense of the space in the building. These differences have a specific value in the configuration of the structural bay. Within the structures based on linear elements, the structural hierarchy of the bay ties in with the relationship between pillars-beam- desk board. On the one hand the structural pattern forms an isotropic spatial cell reiterated in a multi-directional way; on the other the structural pattern forms a galleria, in which the position and the shape of structural elements determines a longitudinal development along a single direction (Fig.1). 


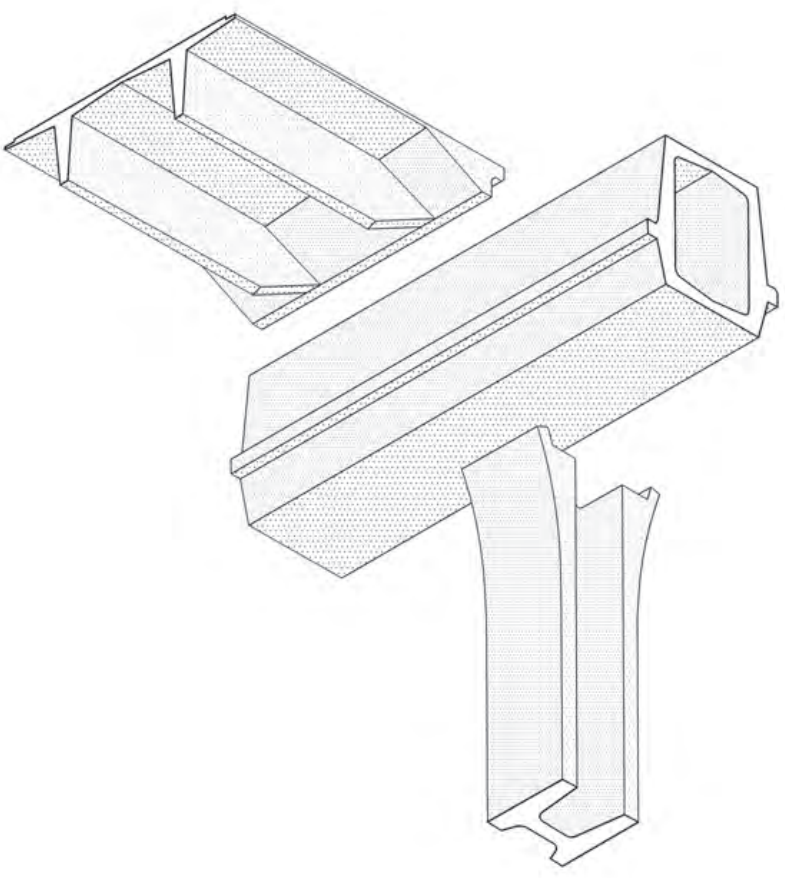

Figure 3. Bay'S Techtonics Assembly of Kodak Factory in Marcianise. Arch. Gianluigi Ghò, 1972. Outline proposal drawing coming from Archivio Privato Gianluigi Ghò, Milano, (C)Archivio gigi ghò (authorized reproduction).

The structures based on form working elements present two kind of structural continuum. The first one has an horizontal development, such as the slab or the membrane that forms a continuous coverage. The second one has a vertical development such as the modular central support shell, in which the membrane and the pillars forms a unique monolithic element.

Regarding the structures based on linear elements applied to reinforced concrete prototypes for industry, it is possible determine another specific quality that joins, cross-cutting, some experiences of the individual designers.

As a consequence of the industrial building programme, that includes the need of a sophisticated technological system, the "trilithic system" of the new reinforced concrete prototypes is enhanced by new figurative aspects. Indeed, there are many cases which shows that each element of construction does not depend only on structural need; it becomes an integrated element available to resolve the issue of vertical lighting, capable of contain inside the technological systems and ensuring an ease of assembly.

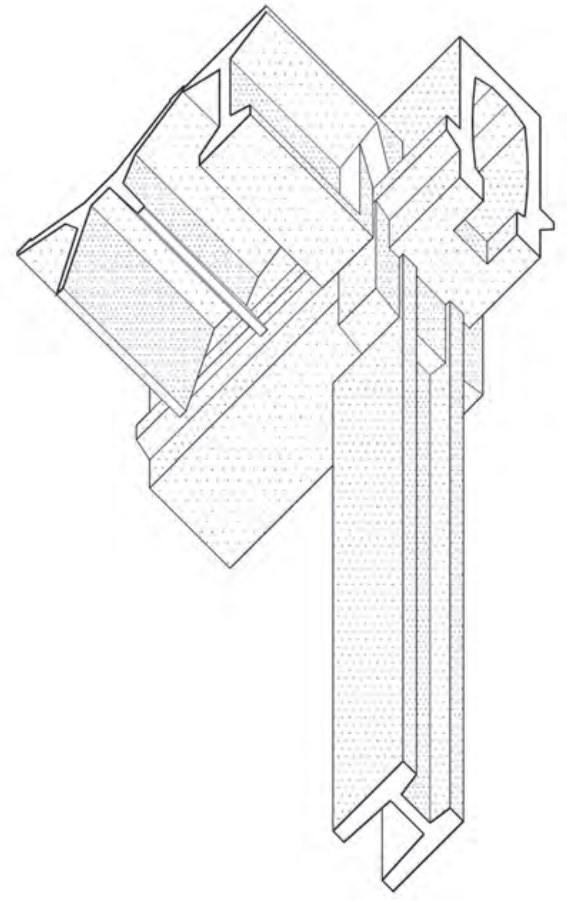

Figure 4. Bay'S Techtonics Assembly of Kodak Factory in Marcianise. Vito Quadrato. 2017. Riproduction of the Executive Design of the Bay based on the drawings coming from Archivio Privato Gianluigi Ghò, Milano.

The solution proposed by some Italian architects and engineers includes the adoption of the hollow structural form. Hence, the hollow form optimises the employment of the concrete by making the most out of the fact that in the concrete construction only a part of the section withstands mechanical loads.

The figurative result of this practical need is substantial: the structure acquires a great thickness, its elements provide for an internal void that in some cases are hidden, in other cases, it reveals the impressive mass of the technological systems, converting an aesthetic problem in an expressive opportunity for the design process.

Francesco Cacciatore belongs to Louis I. Kahn the aware adoption of the structural thickness poetics, which revisits the tradition of Egyptian and Roman architecture. At the end of the day , Kahn's experimentations on the issue of hollow structural form, as Cacciatore says, starts from " the practical need to address the problem arising from the growing number of technological systems, installed within the buildings as from the second half of 20th century in the United States"11. 
Aldo Favini, Marco Zanuso, Antonio Migliasso, Eduardo Vittoria, Carlo Rusconi Clerici, Nello Renacco, as well as Kahn elaborated a sort of rèaction poètique in order to resolve a technological problem in an architectural way (Fig. 2). In this sense the Necchi factory in Pavia and the Olivetti factory in Merlo, designed by Marco Zanuso, are emblematic: the ventilation system nozzle comes out from the head of the beam, becoming a figurative motif within the facade. Regarding Zanuso's prototypes Manolo de Giorgi recognizes the creation of a new architectural order, that he called impianto-struttura, within "the pipes enhanced thrilitic horizontal and vertical elements that does not confine itself to support bending forces, but bring the lifeblood of the architecture. The impianto-struttura results in a new order"12. The idea of hollow elements defines, according to Reyner Banham, "a solution to a deep intellectual and moral need: to be able to see the difference between the building, which it assumed as permanent and technological system, that will hopefully be temporary"13.

Hence, the Italian authors' goal is to absorb within the structure a high level of added complexity. This aspect influences not only the form of the structural elements but also the system of dimensional relationship existing between the same elements, as shown in picture (Fig. 2). For example, in the case of box section beams use, the great contour of ventilation system determines a sort of structural gigantism of the beam, approximately 3 meters high.

The Kodak factory in Marcianise, designed by architect Gianluigi Ghò and engineer Aldo Favini between 1972 and 1975, seems to be explanatory in order to understand the adoption of the hollow concrete structural form applied to the new industrial prototypes. This factory consists of a single-storey building, ranging over $12,500 \mathrm{~m}^{2}$ and it adopts a structural grid $15 \mathrm{~m} \times 15 \mathrm{~m}$. Some original drawings, coming from the Gianluigi Ghò's private archive, shows the system of the bay with a focus on the connection between beam and support (Fig. 3). Therefore, the bay becomes the core generator of the whole design. Ghò begins an inverse design process, starting from the structural detail concept of the building to the development of this detail in all factory. This is also demonstrated by some drawings coming from the executive project, in which a process of formal evolution is discernible when compared with drawings of outline proposal (Fig. 4). The bay of this grid consists of prefabricated linear elements: a pillar, a board beam, a box section beam, a tile. Each of these elements has a specific design that emphasizes a plastic and three-dimensional character. This idea of hollow structural form responds, according to the designer, to "the need to employ for static purpose the contours coming out from technological systems (ventilation, water drainage etc.); these equipment are strictly demanding, due to specific internal needs" 14

The pillar has a dis-symmetrical plan "H" shape, which allows the arrangement of, on the one hand the strut of the water ridge, and on the other hand, the strut of ventilation system. The beam is shaped

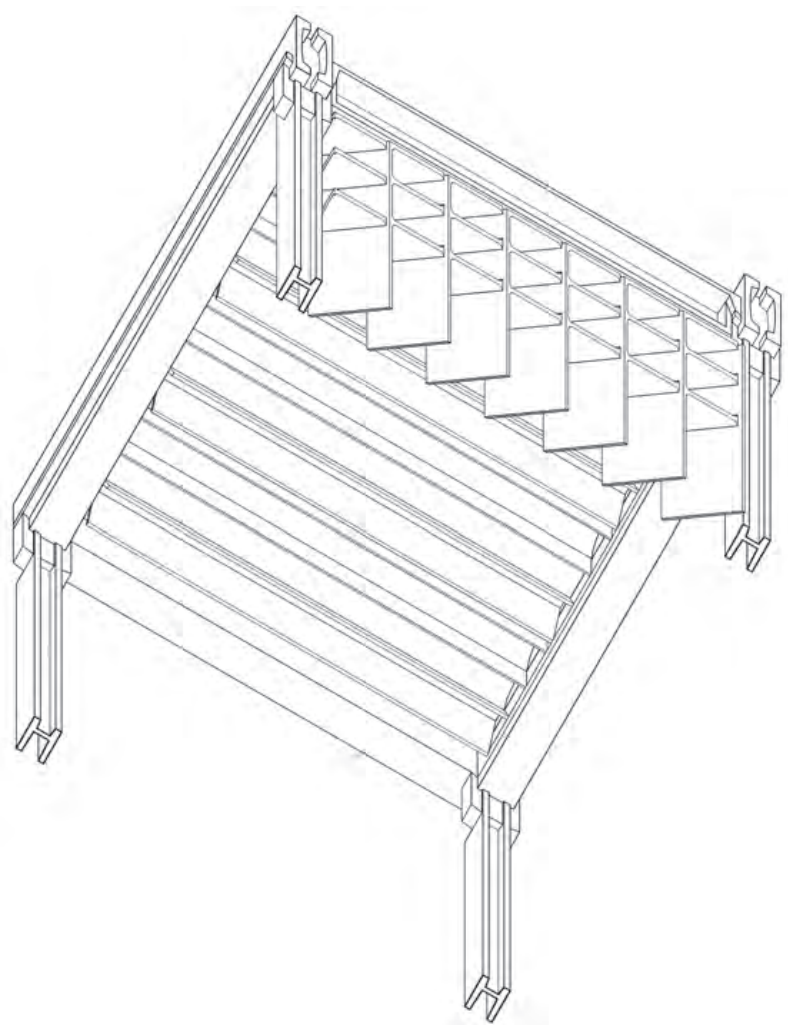

Figure 5. Axonometric view of spatial module. Vito Quadrato. 2017. Reproduction of the Executive Design of the Bay based on the drawings coming from Archivio Privato Gianluig Ghò, Milano.

in section as a box girder with two shelves for the place of secondary system of coverage, such as the tile. The tile is "X" shaped, relating to the bending action, consents to improve the flow of ventilation system. The final configuration of the bay presents, in addition to the elements of the previous slide, the board beam in section double $T$ shaped, which demarks the structural grid and the brise-soleil system, which defines the rhythmic design of the facade. Each prefabricated panel of the brise-soleil system consists of vertical plates oriented in 45 degrees and horizontal shafts (Fig. 5). The plan shows how the designer inflects this spatial module (Fig. 6): the facility is cross-shaped in order to isolate two cores of the productive process, the laboratories to the West and the storages to the East. In the middle, a central spine separates the two cores, providing for the joint distribution, the offices and the other services. The cross-shaped plan revisits the cardo and decumano partition, typical of this geographical area. 

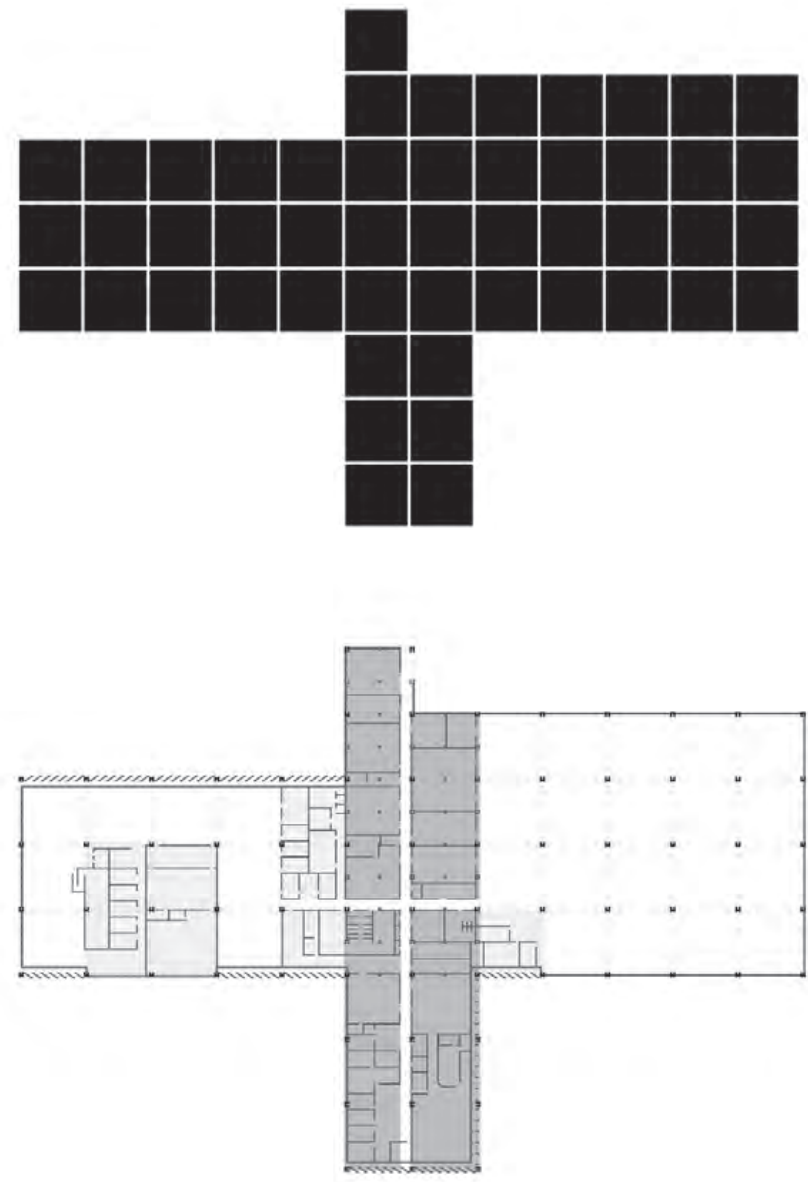

Figure 6. Plan of the Kodak factory in Marcianise. Vito Quadrato, 2017. Reproduction of the Executive Design of the Bay based on the drawings coming from Archivio Privato Gianluigi Ghò, Milano.

\section{Conclusions}

The technical dimension is not subject to the architectural design or a content of a posteriori managing by the designer. On the contrary, it is one key to the design process that introduces a new figurative and spatial dictionary, contributing to create the built form; each element of the structure has a multi-tasking complementarity that goes through a process of the curving-out of the structural materials.

It can there fore be concluded that the concerned reinforced concrete prototypes for industry represents a fundamental experience within the industrialisation tendency to homologate the prefabricated concrete construction. This research consents us to admit these building as Italian historical heritage; the on-going study has the goal to recognize the specific qualities of these buildings that seems to consist of the concept of structural pattern with a pronounced architectural character. The nature of these structural patterns is fundamental in order to develop strategies of transformation compatible with their special architectural and historic merit.

\section{Bibliographic references}

- Annalisa Trentin and Tomaso Trombetti, Architettura e costruzione. La declinazione strutturale da Gustave Eiffel a OMA, Macerata: Quodlibet studio, 2016

- Daniel L. Schodek, Strutture, Bologna: Pàtron editore, 2008.

- Francesco Cacciatore, II muro come contenitore di luoghi. Forme strutturali cave nell'opera di Louis Kahn, Siracusa: LetteraVentidue edizioni, 2016.

- Franz Graf, Angelo Mangiarotti. La tettonica dell'assemblaggio. The Tectonics of Assembly, Cinisello Balsamo: Silvana Editoriale, 2015.

- Gaetano Minnucci and Adalberto Libera, Introduzione all'esposizione in $1^{\circ}$ Espozione Italiana di Architettura Razionale. Roma: De Alberti,1928.

- Giancarlo Nuti, "Rapporti tecnici ed espressivi tra la materia e la struttura", Edilizia Moderna, 82-83, (1963).

- Giulio Barazzetta, "Profili e problemi della prefabbricazione italiana", La Cultura della Tecnica, vol. 27 (2016).

- Giulio Carlo Argan, "Modulo-misura e modulo oggetto" in La Casa, 4 (1957).

- Giulio Pizzetti, "Intuizione e linguaggio analitico nell'ingegneria e nell'architettura" Casabella-continuità, 216 (1956)

- Jacques Gubler, “La campata è un tipo?”, Casabella, 509-510 (1985).

- Kenneth Frampton, Tettonica $e$ architettura. La poetica della forma architettonica nel XIX eXX secolo, Milano: Skira, 2005.

- Laura Biraghi, "Stabilimento Kodak di Caserta" in L'industria italiana del cemento, 10 (Ottobre, 1976)

- Manolo De Giorgi, "Un vedutista lombardo del XX secolo" in Marco Zanuso Architetto, edited by Manolo De Giorgi, Milano: Skira, 1999

- Mario Manieri Elia "Alfabeto di Cemento" in Nervi oggi, edited by Luigi Ramazzotti, Roma: Edizioni Kappa, 1983.

- Massimiliano Savorra, La Forma e la struttura. Felix Candela, gli scritti, Milano: Electa, 2013

- Renato Capozzi, L'architettura dell'ipostilo, Firenze: AION edizioni, 2016.

- Reyner Banham, Ambiente e tecnica nell'architettura Moderna, Bari: Laterza, 1995.

- Riccardo Dirindin, Lo stile dell'ingegneria. Architettura e identità della tecnica tra il primo modernismo e Pier Luigi Nervi, Venice: Marsilio Editore, 2010.

- Vittorio Ugo, I /uoghi di dedalo. Elementi teorici di architettura, Bari: Dedalo edizioni, 1991.

Vito Quadrato (Bari,2/1/1990). Ph.d student of the doctoral programme "Architettura: innovazione e patrimonio", Università di RomaTRE/ Politecnico di Bari. His research interest regards the relationship between Form and structure in architecture. In this connection his thesis research investigates on "the bay as structural and spatial device in the Italian factory (1955-1975)". He is Assistant professor at Laboratorio di progettazione Architettonica I, Politecnico di Bari, Department of Civil Engineer and Architecture. He is Architect at (dp)a studio, firm based in Bari working on housing and interior design. He graduated at Politecnico di Bari in 2015 with a thesis on the Albanian Socialist industrial heritage, selected between the best fifty thesis research from all over the world by Archiprix ed. 2017. 


\section{Notes}

1 Gaetano Minnucci and Adalberto Libera, Introduzione all'esposizione in $1^{\circ}$ Espozione Italiana di Architettura Razionale. (Roma: De Alberti,1928), 6-7.

2 On the interpretation of this Manifesto see: Riccardo Dirindin, Lo stile dell'ingegneria. Architettura e identità della tecnica tra il primo modernismo e Pier Luigi Nervi, (Venice:Marsilio Editore,2010), 116

3 Felix Candela "L'opera di Pierluigi Nervi" in La Forma e la struttura. Felix Candela, gli scritti, ed. Massimiliano Savorra, (Milano: Electa, 2013) 132. Translation from Italian to English by the author.

4 Mario Manieri Elia "Alfabeto di Cemento" in Nervi oggi ed. Luigi Ramazzotti, (Roma: Edizioni Kappa, 1983) 23-26. Translation from Italian to English by the author.

5 Manolo De Giorgi, "Un vedutista lombardo del XX secolo in "Marco Zanuso Architetto" in Marco Zanuso Architetto ed. Manolo De Giorgi (Milano: Skira, 1999) 19. Translation from Italian to English by the author.

6 G. Pizzetti, "Intuizione e linguaggio analitico nell'ingegneria e nell'architettura" CasabeIla-continuità 216, (April 1956), 50-54

7 The term is being borrowed by: Franz Graf, Angelo Mangiarotti. La tettonica dell'assemblaggio. The Tectonics of Assembly (Cinisello Balsamo: Silvana Editoriale, 2015).

8 Giulio Carlo Argan, "Modulo-misura e modulo oggetto" in La Casa, 4 (Gennaio, 1957) 36.

9 Vittorio Ugo, I luoghi di dedalo. Elementi teorici di architettura, (Bari: Dedalo edizioni, 1991) 124-125.

10 The distinction between active structures and passive structure was proposed by: Felix Candela, "Stereostrutture" in in La Forma e la struttura. Felix Candela, gli scritti, ed. Massimiliano Savorra, (Milano: Electa, 2013) 140. Translation from Italian to English by the author.

11 Francesco Cacciatore, , II muro come contenitore di luoghi. Forme strutturali cave nell'opera di Louis Kahn, (Siracusa: LetteraVentidue edizioni, 2016), 73.

12 Manolo De Giorgi, "Un vedutista lombardo del XX secolo in "Marco Zanuso Architetto" in Marco Zanuso Architetto, ed. Manolo De Giorgi (Milano: Skira, 1999) 19. Translation from Italian to English by the author.

13 Reyner Banham, Ambiente e tecnica nell'architettura Moderna. (Bari: Laterza, 1995) 132 Translation from Italian to English by the author.

14 Laura Biraghi, "Stabilimento Kodak di Caserta" in L'industria italiana del cemento 10 (Ottobre, 1976), 653. Translation from Italian to English by the author. 